Article

\title{
Residents' Attention and Awareness of Urban Edible Landscapes: A Case Study of Wuhan, China
}

\author{
Qijiao Xie ${ }^{1,2}$, Yang Yue ${ }^{1}$ and Daohua $\mathrm{Hu}^{1, *}$ \\ 1 School of Resources and Environmental Science, Hubei University, Wuhan 430062, China; \\ xieqijiao@126.com (Q.X.); yueyang428@163.com (Y.Y.) \\ 2 Hubei Key Laboratory of Regional Development and Environmental Response (Hubei University), \\ Wuhan 430062, China \\ * Correspondence: hdh@hubu.edu.cn; Tel.: +86-027-8866-1699
}

Received: 1 November 2019; Accepted: 11 December 2019; Published: 13 December 2019

\begin{abstract}
More and more urban residents in China have suffered from food insecurity and failed to meet the national recommendation of daily fruit and vegetable consumption due to rapid urbanization in recent years. Introducing edible landscapes to urban greening systems represents an opportunity for improving urban food supply and security. However, residents' opinion on urban edible landscapes has rarely been discussed. In this study, questionnaire surveys were performed in eight sample communities in Wuhan, China, to collect the information on residents' attention and awareness of urban edible landscapes. Results indicated that nearly one-third of the respondents were unaware of edible landscapes before the interview. Most residents thought that an edible landscape could promote efficient land use $(57.26 \%)$ and express special ornamental effects $(54.64 \%)$, but quite a few didn't believe that growing edible plants in urban public spaces could increase food output $(37.10 \%)$ and improve food quality (40.12\%). Overall, $45.65 \%$ and $32.73 \%$ of the growers performed their cultivation behavior in private and semiprivate spaces, respectively. Lack of public areas for agriculture use was regarded as the main barrier restricting the development of urban horticulture by $55.86 \%$ of growers and $59.51 \%$ of non-growers. The residents were also worried about their property manager's opposition, possible conflicts, and complex relationships with their neighbors. Food policies and infrastructure support from local governments and official institutions were needed to ensure the successful implementation of edible landscapes in urban areas.
\end{abstract}

Keywords: edible landscape; food security; urban horticulture; community garden

\section{Introduction}

Rapid urbanization leads to the increase of urban population and the replacement of agricultural lands by construction lands. With the increasing demand for food, city dwellers have to rely on processed food or that transported over long distances, which results in nutrient loss and high food prices. To some extent, the urbanization process reduces food availability and food accessibility. Food security, that is "when all people, at all times, have physical and economic access to sufficient safe and nutritious food that meets their dietary needs and food preferences for an active and healthy life (FAO 2008)" [1], thus will be greatly challenged. To solve this problem, some related research has been conducted. Subsistence farming in urban areas was regarded as a strategy for improving food and nutrition security due to the easy access to food, especially in developing countries [2-4]. Edible elements such as vegetables, fruits, herbs, and crops were introduced to urban public spaces in many countries [5-7]. This created a new landscape, characterizing both an aesthetic effect and food production, defined as edible landscape. Besides the traditional benefits of carbon sequestration, rainwater retention, and heat island mitigation $[8,9]$, it also has irreplaceable advantages in alleviating 
food safety crisis, strengthening social cohesion, undertaking science popularization education, and enriching urban species diversity [10-12].

Orsinia et al. reported that the annual output of fruits and vegetables per $\mathrm{m}^{2}$ could be as high as $50 \mathrm{~kg}$ [13]. Effective implementation of urban edible landscape strategy can meet $15 \%-20 \%$ of the global food demand [14]. By being engaged in food planting, urban residents can save transportation costs, reduce food miles, and obtain safety food. Urban horticulture is the main source of daily food and nutrition, especially for low-income residents in some developing countries $[15,16]$. It provides a way for retired people and housewives to integrate into society $[17,18]$, which is of great significance for easing social conflicts and stabilizing social relations [19]. Residents feel close to nature by participating in cultivation activities, which deepens their understanding of the urban ecosystem [20]. The integration of edible plants with ornamental ones increases species diversity in urban areas. This helps to maintain the stability of the urban ecosystem [21] and promote sustainable urban development [22].

The relationships between urban and rural, human and nature, and industry and agriculture have gradually become out of balance. As a part of the urban green infrastructure, the edible landscape plays an important role in improving the environment, maintaining self-supporting systems, and enriching green-space functions. More than $80 \%$ of community gardens in New York were arranged for cultivating edible plants [9]. In New Zealand, $71 \%$ of early education schools and $52.9 \%$ of primary and secondary schools have edible gardens $[23,24]$. Germany built Andrnach, the first "edible city" in history [25]. In addition, the edible landscape has created considerable ecological, economic, and social value for cities. Kulak et al. reported that edible landscapes could reduce the emission of greenhouse gas in the London Sutton district by 34 tons per $\mathrm{hm}^{2}$ in a year, which was higher than the carbon sequestration rate of traditional green lands [26]. Smith et al. confirmed that the average productivity of community gardens in the United States in 2010 was $\$ 15.19$ per $\mathrm{m}^{2}$ [27]. Meanwhile, Orsiniab et al. concluded that $77 \%$ of Bologna's agricultural output came from urban edible landscapes [28]. Growing edible plants in Brazilian cities reduced the food insecurity index from $30.2 \%$ in 2009 to $22.6 \%$ in 2013, so as to guarantee the health of urban residents [12].

For developing countries, food security is the guarantee to reduce social conflicts and maintain social stability [29-31]. In recent years, much attention has been paid to urban food insecurity in China. More and more Chinese experts and urban planners have realized the significance of developing edible landscapes in cities. Activities of planting food species in urban areas require residents' negotiation and collaboration, since every dweller acts as a participant and beneficiary in this process. However, what the Chinese residents' opinion is on edible landscapes has rarely been discussed [32-34]. This study, therefore, aimed to understand city dwellers' perception of edible landscapes and what factors contribute to their development. The specific objectives were as follows: (1) to find out urban residents' awareness of edible landscapes; (2) to investigate residents' experience of growing food species in their daily life; (3) to identify the possible constraints to the implementation of urban edible landscapes in China; and (4) to discuss the key points of policies related to edible landscapes in the future. The study can provide references for the construction of edible landscapes in emerging communities or public spaces in China or other developing countries undergoing rapid urbanization.

\section{Methods}

\subsection{Study Area}

Wuhan $\left(113^{\circ} 41^{\prime}-115^{\circ} 05^{\prime}\right.$ E, $\left.29^{\circ} 58^{\prime}-31^{\circ} 22^{\prime} N\right)$, the capital city of Hubei Province in China, is located in the east of the Jianghan plain and at the confluence of the Yangtze River and the Hanjiang River (Figure 1a). It belongs to the north subtropical monsoon climate, with four distinct seasons and abundant rainfall, which is suitable for crop growth. As a result of its strong economic power and early modernization, Wuhan is more urbanized and has a population of over 11 million. As an ecological garden city, Wuhan has been committed to improving the urban ecology and living environment through landscape greening, and the green area has reached $1510 \mathrm{~km}^{2}$. In recent years, Wuhan has 
been experiencing rapid urbanization. Urban construction extent sprawls outward around the city center, forming a typical ring-shaped pattern. This study was mainly carried out inside of the 3rd ring-road of Wuhan (Figure 1b), which covers an area of $628 \mathrm{~km}^{2}$.

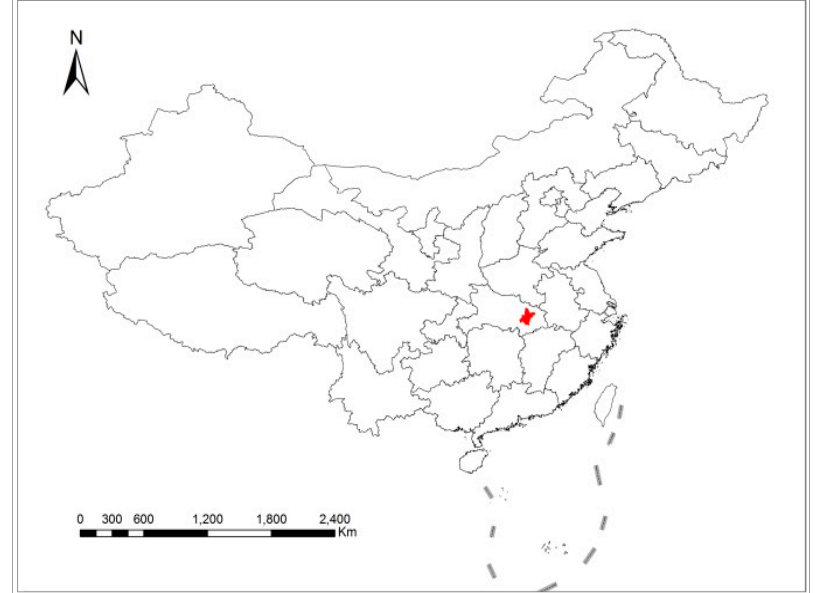

(a) Location of Wuhan in China.

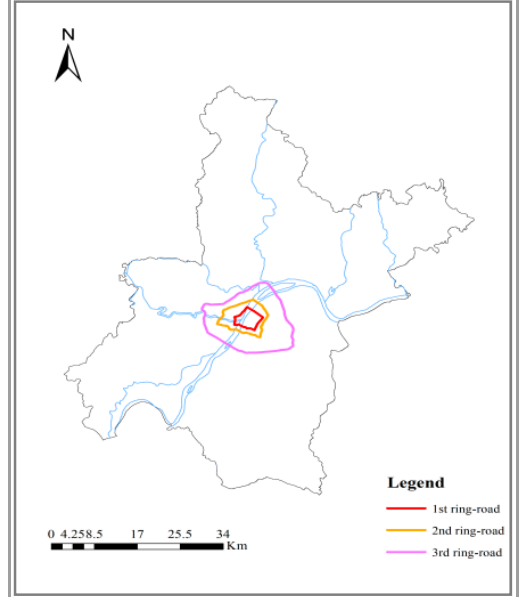

(b) Location of the study area in Wuhan.

Figure 1. Location of the study area.

\subsection{Questionnaire}

The semi-closed questionnaire was designed with three main parts: declaration, personal information, and questions about the residents' attitudes toward edible landscapes. To ensure the respondents' right to know about the investigation, some information on edible landscapes and the objective of this survey were stated at the beginning of the questionnaire. In addition, the anonymity of the questionnaire and the security of the personal information of the interviewees were also declared. Respondents' characteristics, such as their gender, age, and educational status, were recorded. We then investigated the knowledge and perception of urban residents of edible landscape, including the cognitive channel, awareness of edible landscapes, and their experience shown on edible species and planting space. Barriers that restricted the implementation of the Edible Landscape Project from the perspective of growers and non-growers were also covered. All activities were approved by the Academic Committee and Professor Committee of the School of Resources and Environmental Science, Hubei University (Approval No. ZH20180301). A small range of presurvey research was conducted in order to observe the respondents' reactions, and the standard time for complete responses was recorded. Questions that respondents were hesitant about were adjusted, aiming to make the information more direct and concise.

\subsection{Data Collection}

Taking into consideration the uniformity and representativeness of the interviewees, as well as the geographical location, construction age, and the green coverage of the communities, eight typical residential areas in Wuhan were selected as the main implementation area of the questionnaire survey, as shown in Table 1. These eight sample communities were evenly distributed in Wuhan urbanized area, as far as possible, from the inner city to the 3rd ring-road. The areas of the selected communities varied from 60,000 to $5,500,000 \mathrm{~m}^{2}$, and the green coverage was $20 \% \sim 40 \%$. The communities were built 6 40 years ago, with 8000 180,000 residents.

The formal survey was conducted from April to June in 2018. To keep the same inquiry tone and interpretation, unified training was conducted for investigators before the interview. Residents of different ages were interviewed face-to-face in public spaces, such as garden tours, vegetable markets, or shopping malls near the study communities. At the same time, an online questionnaire survey was also conducted, as a useful supplementary in order to improve the response rate and to attract younger 
participants. The online survey was distributed to the residents through instant-messaging apps, such as QQ groups or WeChat groups, with the assistance of the community property owner committees or the neighborhood committees of the eight residential areas.

Table 1. Basic information on the eight investigated communities.

\begin{tabular}{cccccc}
\hline Community & Location & Years & Area $\left.\mathbf{( m}^{\mathbf{2}}\right)$ & Population & Green Coverage (\%) \\
\hline Tiandiyujiang & Inside 1st ring-road & 8 & 125,000 & 8000 & 30.0 \\
Xujiapeng Changlun & Inside 1st ring-road & 40 & 60,000 & 11,000 & 20.0 \\
Parrot Community & 1st-2nd ring-road & 19 & 120,000 & 7000 & 35.0 \\
Tongxin Community & 1st-2nd ring-road & 14 & 160,000 & 8200 & 26.7 \\
Baibuting Community & 2nd-3rd ring-road & 24 & $5,500,000$ & 180,000 & 36.0 \\
Changqing & 2nd-3rd ring-road & 22 & $4,500,000$ & 120,000 & 40.0 \\
Community & Outside 3rd ring-road & 19 & 250,000 & 15,000 & 38.0 \\
Golden Harbor & Outside 3rd ring-road & 6 & 130,000 & 3000 & 20.0 \\
Gezhouba Sun City & Outso & \\
\hline
\end{tabular}

\subsection{Data Analysis}

The collected questionnaire results were preliminarily distinguished according to the consistency of contextual logic and the response time. Questionnaires with incomplete or illogical answers were eliminated. For example, those who chose " $F$ " as the answer for Question 7 could only choose " $F$ " for answering Question 8 instead of other options (shown in Appendix A). Otherwise, it was out of logical consistency and invalid. The reasonable response time was determined in the phase of pre-investigation, with the value of $72 \mathrm{~s}$. The questionnaires with the answer time of far less than $72 \mathrm{~s}$ were defined invalid and excluded. Then the response data were entered into an Excel database and counted separately, according to different issues.

\section{Results}

\subsection{Characteristics of Interviewees}

A total of 496 residents were interviewed through questionnaires. Their basic information of gender, age, education level, and length of residence in Wuhan is presented in Figure 2. Because not all residents were cooperative, those people who were willing to be interviewed expressed their attention to the edible landscape to a certain extent. Female residents paid more attention to edible landscapes than male ones, with a higher proportion (59.88\%) than that of the males $(40.12 \%)$. Of 496 respondents, 341 were between 20 and 40 years old, accounting for the largest proportion, which was $68.75 \%$. Then there were respondents aged $40-60$ years, which accounted for $25 \%$. Those who were over 60 years old and less than 20 years old were uncooperative with the interview. The younger respondents and the elder ones only accounted for $2.62 \%$ and $3.63 \%$, respectively.

For the education level, $60.96 \%$ of the respondents had received an undergraduate education. Those who had postgraduate education and senior high school education levels accounted for $18.35 \%$ and $15.12 \%$, respectively. Only $5.85 \%$ of the respondents had education experience in junior high school and below. In total, $66.13 \%$ of respondents settled in Wuhan for more than 10 years. The interviewees who lived in Wuhan for 2-5 years and 5-10 years made up a similar proportion, with the values of $12.90 \%$ and $12.70 \%$, respectively. Only $8.27 \%$ of the respondents lived in Wuhan for less than two years. 


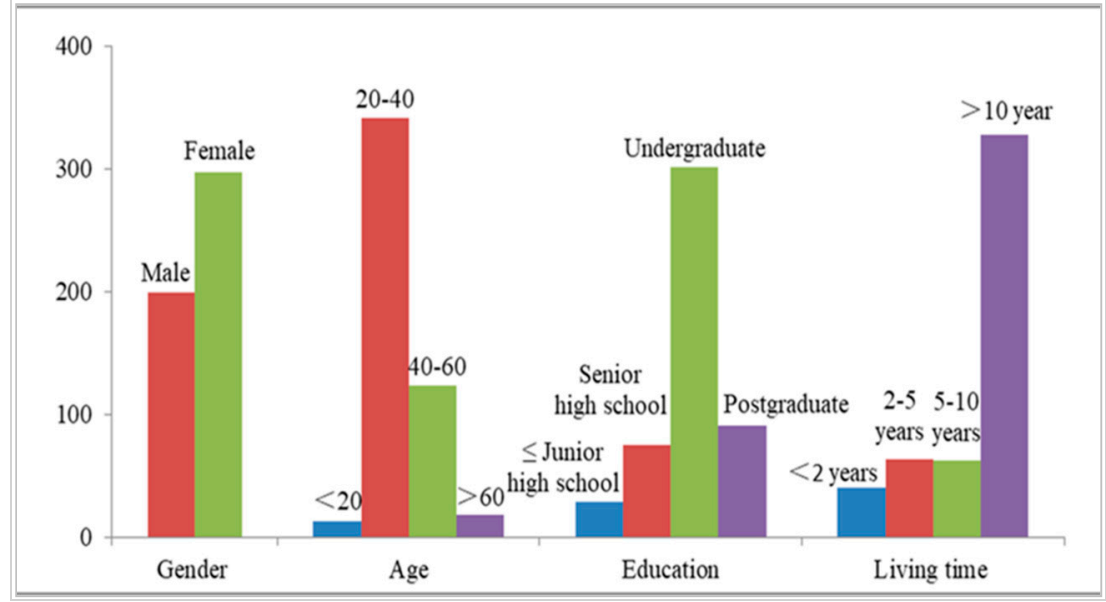

Figure 2. Characteristics of the respondents $(n=496)$.

\subsection{Perception of Edible Landscape}

Community residents' awareness and perception of edible landscapes are of great significance to the implementation of food planting in cities, especially in urban public spaces. For most Chinese urban residents, the edible landscape is new to community gardens. As shown in Table 2, of the 496 respondents, $32.06 \%$ were unaware of edible landscapes before this interview, $23.79 \%$ learned about edible landscapes and the related information from internet, and $20.97 \%$ were introduced to edible landscapes by their relatives or neighbors. A minority of the interviewees were informed about the edible landscape through magazines (5.44\%), television programs $(6.65 \%)$, and other ways $(11.09 \%)$.

In this study, six typical benefits of edible landscapes were displayed, such as providing food production, high food quality, natural education, physical exercise, efficient land use, and distinct visual effects. As Table 3 shows, 284 respondents believed that food planting in community gardens could promote efficient land use, accounting for the largest proportion of $57.26 \%$, and $54.64 \%$ accepted the distinct visual effect of edible landscape to the traditional one in public areas. Half of the respondents said that planting edible species in public areas provides the opportunity for natural education for urban residents, especially for children, and $49.19 \%$ thought that cultivating behavior could enhance their physical exercise and help them relax in their spare time. Only $37.10 \%$ and $40.12 \%$ believed that food planting in community gardens could provide food products and improve food quality.

Table 2. Ways to learn about the edible landscape $(n=496)$.

\begin{tabular}{ccc}
\hline Cognitive Channels & Number & Proportion \\
\hline By reading newspapers and magazines & 27 & $5.44 \%$ \\
By watching TV & 33 & $6.65 \%$ \\
By surfing on Internet & 118 & $23.79 \%$ \\
By the introduction of relatives and neighbors & 104 & $20.97 \%$ \\
By other ways & 55 & $11.09 \%$ \\
Be unaware of it & 159 & $32.06 \%$ \\
\hline
\end{tabular}

Table 3. Residents' awareness on the benefits of edible landscapes $(n=496)$.

\begin{tabular}{ccc}
\hline Benefits of Edible Landscape & Number & Proportion \\
\hline Forming distinct visual effect with traditional landscape & 271 & $54.64 \%$ \\
Improving food quality & 199 & $40.12 \%$ \\
Educating children on the science of nature & 248 & $50 \%$ \\
Enhancing physical exercise and being relaxed & 244 & $49.19 \%$ \\
Promoting efficient land use & 284 & $57.26 \%$ \\
Providing food products & 184 & $37.1 \%$ \\
Be unaware of it & 159 & $32.06 \%$ \\
\hline
\end{tabular}




\subsection{Growing Experience}

Residents' growing experience of edible plants reflected their preference for cultivating location and species. Figure 3 records five common types of planting sites in urban areas. Of the 496 respondents, 163 had no experience growing edible plants in their daily life, accounting for $32.86 \%$ and $30.65 \%$ planted vegetables and small fruits on the balcony, followed by $16.53 \%$ in the courtyard, $8.87 \%$ in other locations, $5.65 \%$ in community vacant land, and $5.44 \%$ on the roof. Among the 333 respondents who had experienced food planting, 152 (45.65\%) performed their cultivation behavior on the balcony, a private place. A total of $82(24.62 \%)$ and $27(8.11 \%)$ respondents planted vegetables and fruits in semiprivate places, namely the courtyard and the roof, respectively. Only $28(8.41 \%)$ interviewees said their planting experience took place in public spaces, such as roadsides, the waterfront, or community gardens.

Figure 4 displays the preference of different growers for planting edible species. The majority of the growers preferred to plant vegetables, such as cucumbers, tomatoes, peppers, eggplants, and towel gourds, with the largest proportion of $71.47 \%$. Fifty-eight respondents planted fruit trees, such as grapes, loquats, peaches and oranges, accounting for $17.42 \%$ of the growers. There were a few people who had planted crops $(6.61 \%)$ and herbs $(3.90 \%)$. Only two respondents planted mushrooms, accounting for $0.60 \%$.

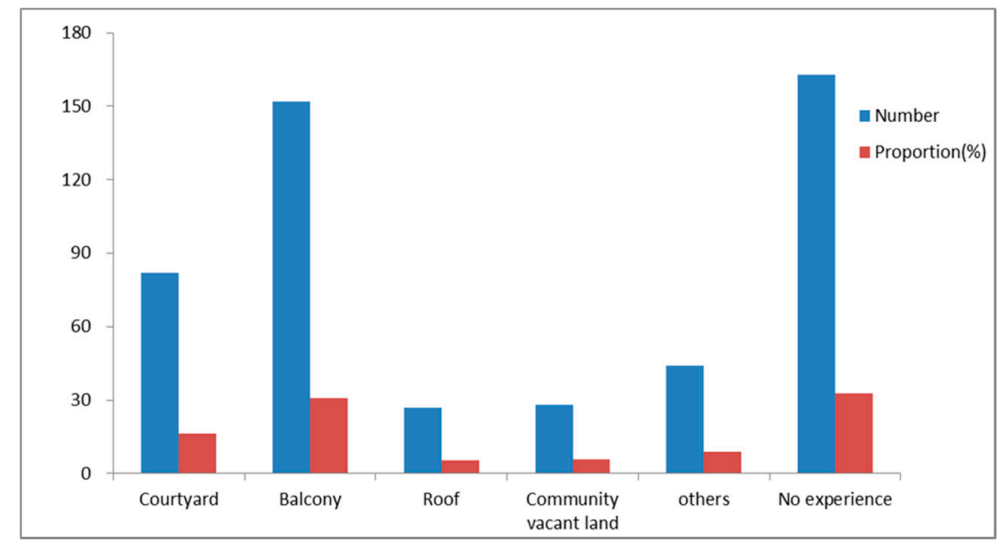

Figure 3. Locations where residents grow edible plants $(n=496)$.

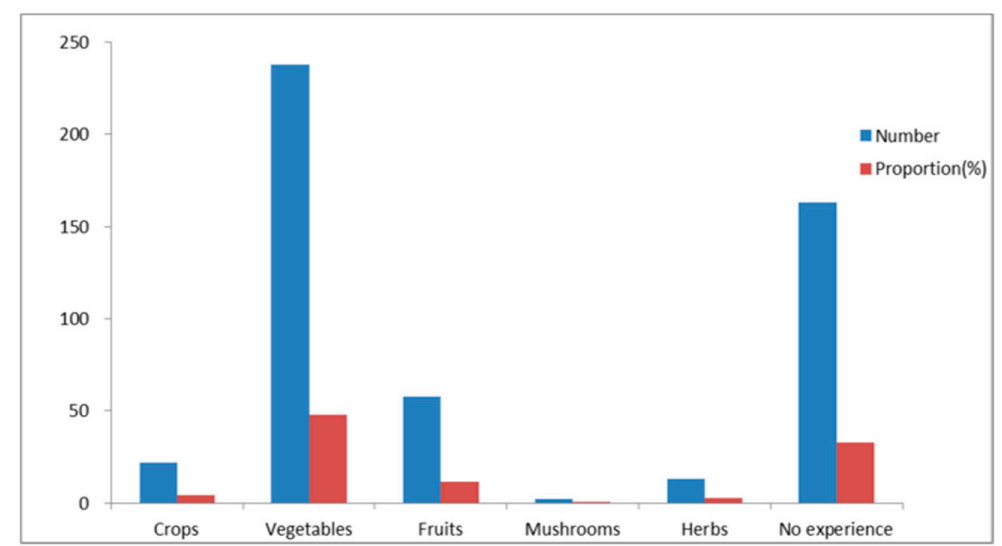

Figure 4. Edible elements urban residents cultivate $(n=496)$.

\subsection{Barriers}

To make it clear what possibly restricted the residents from implementing the Edible Landscape Project, the barriers were discussed. Considering the different understanding of the obstacles in implementing edible landscapes between growers and non-growers, they were discussed separately. 


\subsubsection{Barriers for Growers}

Figure 5 counts the perceptions of 333 growers on the barriers influencing their planting. A total of 186 growers said that the largest trouble was lack of planting spaces, with the proportion of $55.86 \%$. In total, $35.14 \%$ thought that the possible conflicts between growers and non-growers, as well as between residents and property managers, made it difficult to successfully manage the cultivating process; $33.03 \%$ of growers didn't think that they had enough free time for food planting; and $25.83 \%$ and $24.32 \%$ of growers also complained about the difficulty of obtaining plant seeds and fertilizer and lack of help in planting, respectively. In addition, their property manager's opposition, high planting costs, and food process difficulties were regarded as barriers by $19.82 \%, 14.11 \%$, and $16.52 \%$ of growers, respectively.

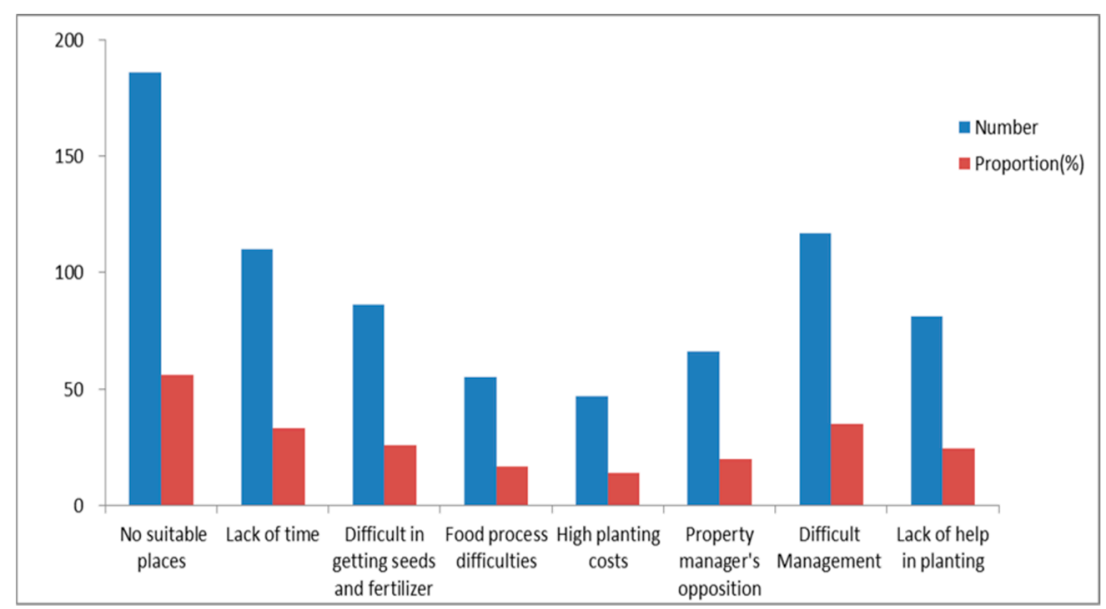

Figure 5. Barriers influencing growers' cultivation activities $(n=333)$.

\subsubsection{Barriers of Non-Growers}

Figure 6 expresses the understanding of 163 non-growers on the barriers constraining their planting. A total of $59.51 \%$ of people thought they had no suitable places to grow edible plants; $47.85 \%$ complained they were too busy to cultivate; $39.88 \%$ of non-growers didn't think they could finish the whole cultivation process only by themselves; and $33.13 \%$ of them gave up planting partly because they were unwilling to face the complex relationships with their neighbors. Other possible barriers, such as a property manager's objections, high planting costs, and difficulties in getting seeds and processing food products also troubled $21.47 \%, 20.25 \%, 19.02 \%$, and $12.27 \%$ of non-growers, respectively, and then prevented them from planting.

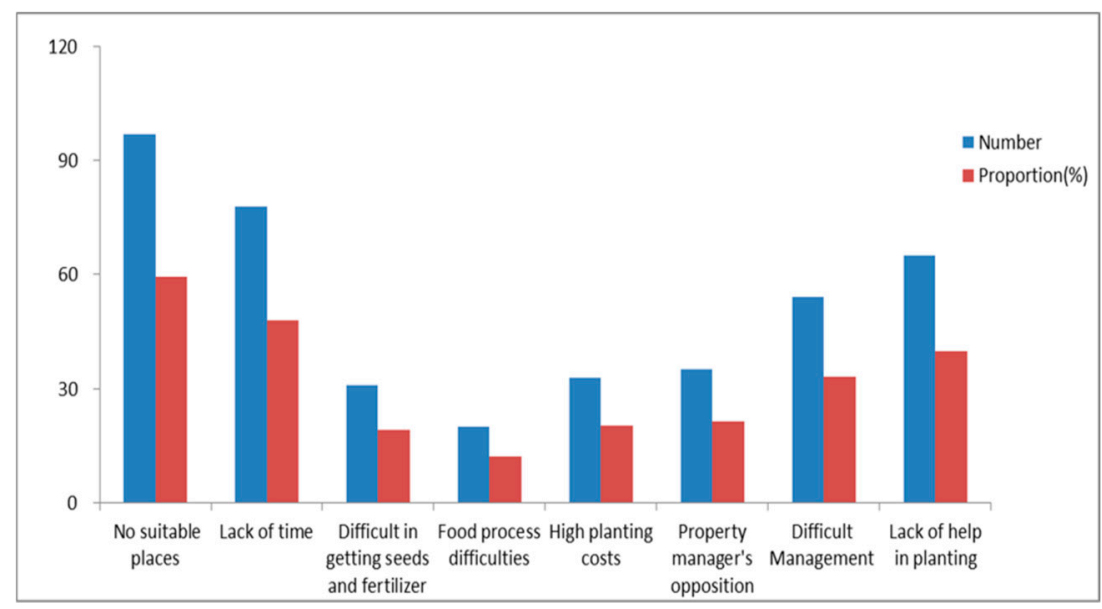

Figure 6. Barriers constraining non-growers' cultivation activities $(n=163)$. 


\section{Discussion}

\subsection{Lack of Awareness of the Benefit of Edible Landscapes in Improving Food Security}

As a kind of urban landscape, the edible landscape has special ornamental and aesthetic effects compared with the traditional ones. This benefit was well recognized by most respondents in our investigation. Instead, the primary service of food production was not reasonably evaluated by the interviewees. Only about $40 \%$ of the respondents believed that growing edible plants in urban areas can actually alleviate the urban food crisis (Table 3). This significantly differed from that of the other countries. In most developing countries, edible landscapes (formerly known as urban horticulture) have been encouraged and promoted in both urban public and private spaces, for they play a vital role in providing food products and improving food quality for urban dwellers [35]. Food production with the yield potential of $50 \mathrm{~kg} / \mathrm{m}^{2}$ vegetables and fruits per year can almost meet the household fresh-food needs of urban residents [13]. The benefit of food producing is regarded as one of the most important services of edible landscapes by the majority of urban residents [36].

Lack of awareness about the benefit of edible landscapes in producing fresh food seriously blocked the residents' enthusiasm for growing food plants. On the one hand, residents don't fully believe that engagement in farming can allow them and their family to consume better and more nutritious diets from fresh vegetables and fruits, so they don't have a strong incentive to grow edible plants. On the other hand, the public does not understand that the implementation of edible landscapes in urban areas can effectively reduce the amount of food import, thus promoting urban food security and stability of urban food systems. They can't accept other residents planting edible species in public areas, such as city parks and community gardens. Correspondingly, the respondents in this study could grow food plants mainly in private or semiprivate areas, such as their balcony and courtyard (shown in Figure 3). Only 5.65\% of the respondents had planting experience in public vacant spaces which were not planned for farming. Improving the urban residents' cognition of edible landscapes is of great significance for the successful implementation of the edible-landscape strategy.

\subsection{Production Potential of Vegetables and Fruits}

To some extent, displaying data is the most intuitive and persuasive way to change residents' cognition. The community gardens in our eight sample plots were designed to meet residents' needs for leisure and entertainment activities. Community residents are used to chatting, jogging, exercising, and playing cards there, so it is hard for them to imagine that these lands could produce fresh and nutritious vegetables and fruits, to meet their daily needs, even though this has already been achieved in many other countries. To provide solid evidence with clear data, the food-production potential of investigated community gardens was calculated. Table 1 lists the detailed information of the sample communities about the community area, greening coverage, and population. If $44 \%$ of the community garden area was used for fruit and vegetable planting [37], with the annual potential yields of $50 \mathrm{~kg}$ per $\mathrm{m}^{2}$ [13], the supply of fruits and vegetables for each sample community was obtained. According to the Dietary Guidelines for Chinese Resident (2016) [38], one Chinese resident needs at least 500-850 g of vegetables and fruits every day, to ensure a healthy diet. The minimum intake of 500 $\mathrm{g}$ per day was used as a reference to estimate the fresh-food demand.

Table 4 displays the supply and demand of fresh vegetables and fruits for each sample community. The annual production of vegetables and fruits had a wide range of 264 to 43,560 $\mathrm{t}$ among different communities, depending on the areas of the community gardens. Residents' annual demand for vegetables and fruits varied from 547.5 to $32,850 \mathrm{t}$, which were currently imported into the cities by long-distance transportation from the nearby suburbs. With the self-production function of community gardens, $14 \%-180 \%$ of the demand for fruits and vegetables can be satisfied. For big communities such as Changqing Community and Baibuting Community, fresh food supply is much more than the demand, with the supply and demand ratio of 1.8 and 1.3, respectively. The total supply-and-demand ratio of fruits and vegetables in estimated areas reached 7 . This meant that there were still a large 
number of fruits and vegetables surplus on the premise of meeting the residents' daily demand. The remaining fruits and vegetables can feed some residents of other communities within this city, which can help to reduce the food import and to improve the city's self-sufficiency.

Table 4. Potential production assessment of eight sample communities.

\begin{tabular}{cccccccccc}
\hline Community & $\begin{array}{c}\text { Tiandi- } \\
\text { yujiang }\end{array}$ & $\begin{array}{c}\text { Xujiapeng } \\
\text { Changlun }\end{array}$ & $\begin{array}{c}\text { Parrot } \\
\text { Community }\end{array}$ & $\begin{array}{c}\text { Tongxin } \\
\text { Community }\end{array}$ & $\begin{array}{c}\text { Baibuting } \\
\text { Community }\end{array}$ & $\begin{array}{c}\text { Changqing } \\
\text { Community }\end{array}$ & $\begin{array}{c}\text { Golden } \\
\text { Harbor }\end{array}$ & $\begin{array}{c}\text { Gezhouba } \\
\text { Sun City }\end{array}$ & Total \\
\hline Supply (t) & 825 & 264 & 924 & 939.84 & 43,560 & 39,600 & 2090 & 572 \\
Demand (t) & 1460 & 2007.5 & 1277.5 & 1496.5 & 32,850 & 21,900 & 2737.5 & 547.5 & $64,774.8$ \\
Ratio (\%) & 56.5 & 13.2 & 72.3 & 62.8 & 132.6 & 180.8 & 76.3 & 104.5 & 699.0 \\
\hline
\end{tabular}

\subsection{Significance of Government's Plan and Management}

The potential benefits of community gardens and other urban open spaces have encouraged many governments to plan specific spaces for food planting [39,40]. Edible parks, community farms, school gardens, and rooftop gardens are the main growing areas in most countries $[9,23,24]$. In China, there were no public spaces planned for agriculture use in urban areas. As shown in Figure 3, 261 of 333 growers in this study conducted their cultivation behaviors in private and semiprivate spaces, such as their balcony and roof garden. Only vegetables and small fruit trees can be planted in the narrow private spaces (shown in Figure 4). Such small-scale planting can't provide enough food products for the residents. They need the local government's systematic plan for the urban food system. The first step is to plan some open or semi-open spaces for urban horticulture [41], which was expected by most of the respondents (see Figures 5 and 6).

Governments play a vital role in the successful integration of different benefits of urban open spaces, such as urban parks, community gardens, and school yards [42-44]. For example, the Canadian national government pursued the People's Food Policy, a national food policy in 2011. In this project, a recommendation to increase local food production through urban agriculture activities was put forward. At the White House, former First Lady Michelle Obama established a vegetable garden and advocated healthy eating and community gardening through her Let's Move initiative. Some local governments in other countries, such as Australia [45,46], Japan [47], and Uruguay [48] have planned to protect urban agriculture lands and support household food production. Urban horticulture plans and the government's political backing can ensure the legitimacy of food planting in public areas and give the needed infrastructure support $[49,50]$. From our investigation, most of the barriers restraining urban residents' planting behaviors, such as lack of cultivation spaces, their property manager's opposition, and possible conflicts and complex relationships (Figure 5) with their neighbors, were associated with the related policies, which could be completely or partly eliminated through the government's guidance and management. Therefore, more and more official institutions and specific policies backed by the government must be established to promote the edible landscape projects.

\subsection{Limitations and Prospects}

Some limitations still existed in this study. First of all, the limited number of respondents and the age proportion of different groups might influence the results. This study was carried out in Wuhan, due to the extensive transportation system and mixed people from all over China. Our investigation was conducted in eight typical communities, taking the geographical location, community age, and resident characteristics into consideration. To some extent, the collected information from 496 respondents could represent the residents' awareness and perception of edible landscapes. Though, due to lack of participation, young respondents below 20 and old ones over 60 accounted for only $6.25 \%$ of the total (Figure 2). Their responses did not fully express the residents' attitudes of the corresponding age groups. Secondly, an online questionnaire was used as an important supplement to the on-site interview in this study. It attracted more residents to participate in the survey and efficiently expanded the sample size. However, if the online respondents had any questions during the questionnaire process, they couldn't be answered in time. This probably led to some small deviations in the results. 
Thirdly, although the Edible Landscape Project has attracted more and more attention from Chinese ecologists and planners, it is still a newcomer to most urban residents. Their understanding of questions in the questionnaire differed from each other, depending on their age, education level, and living background. The answers collected from the questionnaires may not fully reflect their real opinions. Finally, the data in this study were obtained mainly by questionnaire survey. The survey provided enough information on how urban residents responded to the Edible Landscape Project, but it did not provide information about why they had those responses. A combined method of questionnaire survey with in-depth interview is needed, which can be improved in the future.

China has been experiencing rapid urbanization in recent years with expanding urban sprawl. Urban residents have suffered from serious food insecurity and have failed to meet the national recommendation of daily fruit and vegetable consumption [51]. Recently, this issue has attracted great attention from many Chinese scholars and designers [52,53], but there is still a big gap between the development of urban edible landscapes in China and other countries. Table 5 summarizes the residents' awareness of edible landscapes in this study and some other typical studies; this information provides guidance for the future direction in regard to the implementation of edible landscapes in China. In most developed countries, edible elements such as vegetables, fruits, and herbs were introduced into community gardens, school gardens, and home gardens $[4,6,43,45,54]$. This mainly provided the social benefit of natural education for the public $[3,23,24]$, which attracts most urban residents' participation $[37,43]$. Compared with developed countries, most developing countries such as Argentina, Brazil, and Nepal implemented edible landscape projects to provide high-quality food supply $[3,16,36]$. Many housewives were engaged in community and family farming to get crops and fresh food $[6,12,13,55]$, so they expected the horticulture infrastructures to be improved in order to enhance food production $[3,43]$. However, in China, though suffering from food insecurity, urban residents generally believed that growing edible plants in cities serves only to promote land-use efficiency and visual effect and couldn't fully accept the benefit of food production (Table 3); thus, they only planted some vegetables and small fruit trees in their courtyard and on their balcony, as no public places were planned and provided (Figure 5). By comparing our research with previous studies, we find that it is urgent to raise the residents' awareness about the benefits of local food in improving food access and quality. Good communication and cooperation between the government and community residents is the premise that helps guarantee the implementation of an urban food strategy. Food education through official publicity, systematic training, and planting practice in some pilot gardens is encouraged. Government-guided food-system plans and policies are needed to legitimize and institutionalize food planting in urban public spaces.

Table 5. Residents' awareness of the urban edible landscape in different studies.

\begin{tabular}{|c|c|c|c|c|c|}
\hline & \multicolumn{2}{|c|}{ Developed Countries } & \multicolumn{2}{|c|}{ Other Developing Countries } & \multirow{2}{*}{$\begin{array}{c}\text { Wuhan, China } \\
\text { Perspectives }\end{array}$} \\
\hline & Overall Perspectives & $\begin{array}{l}\text { Typical } \\
\text { Countries }\end{array}$ & Overall Perspectives & $\begin{array}{l}\text { Typical } \\
\text { Countries }\end{array}$ & \\
\hline Main purpose & $\begin{array}{c}\text { Social and education } \\
\text { benefits }[3,23,24]\end{array}$ & New Zealand & $\begin{array}{l}\text { Improving food } \\
\text { security }[3,16,36]\end{array}$ & Argentina & $\begin{array}{c}\text { Promoting land-use } \\
\text { efficiency }\end{array}$ \\
\hline Participants & Most residents $[37,43]$ & United States & Female $[6,16,17]$ & South Africa & Female \\
\hline Growing sites & $\begin{array}{l}\text { Community and home } \\
\text { gardens }[4,6,45]\end{array}$ & United States & $\begin{array}{c}\text { Community and home } \\
\text { gardens }[3,12,13]\end{array}$ & Brazil & Courtyard and balcony \\
\hline Edible plants & $\begin{array}{c}\text { Vegetables, fruits, and } \\
\text { herbs }[43,54]\end{array}$ & France & $\begin{array}{l}\text { Vegetables, fruits, } \\
\text { crops, and herbs }[3,55]\end{array}$ & Nepal & $\begin{array}{l}\text { Vegetables and } \\
\text { small fruits }\end{array}$ \\
\hline Main barriers & $\begin{array}{l}\text { Insecurity of future } \\
\text { land access }[7,43]\end{array}$ & Canada & $\begin{array}{c}\text { Insufficient } \\
\text { infrastructure and } \\
\text { services }[3,43]\end{array}$ & Cuba & No suitable places \\
\hline
\end{tabular}

\section{Conclusions}

In this study, a questionnaire survey was conducted to collect information about the residents' attention and awareness of urban edible landscapes in eight sample communities in Wuhan, China. In total, 496 urban residents were interviewed, most of them aged 20 40 (68.75\%). Female residents 
(59.88\%) paid more attention to edible landscapes than male ones $(40.12 \%)$. Those with an undergraduate education background (60.96\%) showed more interest in edible landscapes. Our investigation indicated that nearly one-third of the respondents were unaware of edible landscapes. The respondents learned about edible landscape and the related information mainly from the internet $(23.79 \%)$ and their relatives or neighbors (20.97\%). Most residents thought that edible landscapes could promote efficient land use (57.26\%) and express special ornamental effects (54.64\%), but quite a few didn't believe that growing edible plants in urban public spaces could increase food output (37.10\%) and improve food quality $(40.12 \%)$. Only $67.14 \%$ of the respondents had experience in growing edible plants. They usually performed their cultivation behavior in private or semiprivate spaces, such as their balcony $(30.65 \%)$ and courtyard $(16.53 \%)$, in their spare time. The most frequent edible plants they grew were vegetables (47.98\%) and fruits $(11.69 \%)$. Few public spaces were privately used for food planting, because the government did not plan open spaces for agriculture use, and this was regarded as the main barrier restricting the development of urban horticulture in China. For growers, the three biggest troubles in their planting were lack of planting spaces $(55.86 \%)$, possible conflicts with other residents $(35.14 \%)$, and lack of time $(33.03 \%)$. Meanwhile, for non-growers, the three biggest barriers constraining their planting were lack of suitable places (59.51\%), lack of time (47.85\%), and lack of confidence in their abilities $(39.88 \%)$. These conclusions provide scientific references for the policy decisions and construction of edible landscapes in public spaces in China or other developing countries. This study is still at the preliminary stage for implementing and promoting edible landscapes and has some limitations which need to be counteracted by more research in the future.

Author Contributions: Q.X. designed the research and wrote the manuscript; Y.Y. performed the investigation and data analysis; D.H. provided some effective suggestions and revised the manuscript.

Funding: This research was sponsored by MOE (Ministry of Education in China) Project of Humanities and Social Sciences (19YJCZH195) and the Natural Science Foundation of Hubei Province of China (2019CFB538).

Conflicts of Interest: The authors declare no conflicts of interest.

\section{Appendix A}

\section{Survey on Wuhan Residents' Attention and Awareness of Edible Landscapes Dear Sir/madam:}

Hello! We are from Hubei University. A survey on the attention and awareness of Wuhan residents on edible landscapes is being conducted. This survey is anonymous, and the relevant personal information is confidential. All the information you provide is only for our research, so please feel free to fill in. Thank you for the cooperation!

Note: the edible landscape is a new type of landscape. The main elements are food plants, including cultivated vegetables (such as radish, cabbage, etc.), food crops (such as rice, peanuts, etc.), fruits (such as bananas, grapes, etc.), herbs (such as honeysuckle, mint, etc.), and mushrooms (such as lentinus edodes, enoki mushroom, etc.).
1. Your gender is ( ).
4. You have lived in Wuhan for ( ).
A. Male
B. Female
2. Your age is ( ).
A. $<20$
B. $20-40$
C. $40-60$
D. $>60$
3. Your education background is ( ).
A. Junior high school and below
B. Senior high school
C. Undergraduate
D. Postgraduate
A. $<2$ years
B. 2-5 years
C. 5-10 years
D. $>10$ years
5. How did you learn about edible landscape? ()
A. By reading newspapers and magazines
B. By watching TV
C. By surfing on Internet
D. By the introduction of relatives and neighbors
E. By other ways
F. Unaware of it 
6. What do you think are the main advantages of edible landscape compared with traditional one (multiple choices)? ( )

A. Forming distinct view effect with traditional landscape

B. Improving food quality

C. Educating children on the science of nature

D. Enhancing physical exercise and being relaxed

E. Promoting efficient land use

F. Providing food products

G. Nothing

7. Where do you and your family perform your cultivation activities? ( )
A. Courtyard
B. Balcony
C. Roof
D. Community vacant land
E. Others
F. No experience

8. Which specie do you and your family usually grow? ( )
A. Crops
B. Vegetables
C. Fruits
D. Mushrooms
E. Herbs
F. No experience
9. Which are the main barriers in growing edible plants (multiple choices)? ( )
A. No suitable place
B. Lack of time
C. Difficult in getting seeds and fertilizer
D. Food process difficulties
E. High planting costs
F. Property manager's opposition
G. Difficult management
H. Lack of help in planting

\section{References}

1. FAO. Climate Change and Food Security: A framework Document; Food and Agriculture Organization of the United Nations: Rome, Italy, 2008; Available online: http://www.fao.org/forestry/15538079b31d45081fe9c3dbc6ff34de4807e4.pdf (accessed on 10 December 2019).

2. Obeng-Odoom, F. Underwriting food security the urban way: Lessons from African countries. Agroecol. Sustain. Food Syst. 2013, 37, 614-628. [CrossRef]

3. Eigenbrod, C.; Gruda, N. Urban vegetable for food security in cities. A review. Agron. Sustain. Dev. 2014, 35, 483-498. [CrossRef]

4. Mok, H.F.; Williamson, V.G.; Grove, J.R.; Burry, K.; Barker, S.F.; Hamilton, A.J. Strawberry fields forever? Urban agriculture in developed countries: A review. Agron. Sustain. Dev. 2014, 34, 21-43. [CrossRef]

5. Björklund, J.; Eksvärd, K.; Schaffer, C. Exploring the potential of edible forest gardens: Experiences from a participatory action research project in Sweden. Agrofor. Syst. 2019, 93, 1107-1118. [CrossRef]

6. Taylor, J.R.; Lovell, S.T.; Wortman, S.E. Urban home food gardens in the Global North: Research traditions and future directions. Agric. Hum. Values 2014, 31, 285-305. [CrossRef]

7. Drake, L.; Lawson, L.J. Results of a US and Canada community garden survey: Shared challenges in garden management amid diverse geographical and organizational contexts. Agric. Hum. Values 2015, 32, $241-254$. [CrossRef]

8. Mattsson, E.; Ostwald, M.; Nissanka, S.P.; Pushpakumara, D.K.N.G. Quantification of carbon stock and tree diversity of homegardens in a dry zone area of Moneragala district, Sri Lanka. Agrofor. Syst. 2015, 89, 435-445. [CrossRef]

9. Gittleman, M.; Farmer, C.J.Q.; Kremer, P.; McPhearson, T. Estimating stormwater runoff for community gardens in New York City. Urban. Ecosyst. 2017, 20, 129-139. [CrossRef]

10. Goldstein, B.; Hauschild, M.; Fernández, J.; Birkved, M. Testing the environmental performance of urban agriculture as a food supply in northern climates. J. Clean. Prod. 2016, 135, 984-994. [CrossRef]

11. Sima, R.M.; Micu, I.; Maniutiu, D.; Sima, N.F. Edible landscaping-integration of vegetable garden in the landscape of a private property. Horticulture 2010, 1, 278-283.

12. Medeiros, N.A.; Carmo, D.L.; Priore, S.E.; Santos, R.H.S.; Pinto, C.A. Food security and edible plant cultivation in the urban gardens of socially disadvantaged families in the municipality of Viçosa, Minas Gerais, Brazil. Env. Dev. Sustain. 2019, 21,1171-1184. [CrossRef]

13. Orsini, F.; Kahane, R.; Nono-Womdi, R.; Gianquinto, G. Urban agriculture in the developing world: A review. Agron. Sustain. Dev. 2013, 33, 695-720. [CrossRef] 
14. Abdulkadir, A.; Dossa, L.H.; Lompo, J.P. Characterization of urban and peri-urban agroecosystems in three West African cities. Int. J. Agric. Sustain. 2012, 10, 289-314. [CrossRef]

15. Specht, K.; Siebert, R.; Hartmann, I.; Freisinger, U.B.; Sawicka, M.; Werner, A.; Thomaier, S.; Henckel, D.; Walk, H.; Dierich, A. Urban agriculture of the future: An overview of sustainability aspects of food production in and on buildings. Agric. Hum. Values 2014, 31, 33-51. [CrossRef]

16. Hamilton, A.J.; Burry, K.; Mok, H.F.; Barker, S.F.; Grove, J.R.; Williamson, V.G. Give peas a chance? Urban agriculture in developing countries. A review. Agron. Sustain. Dev. 2014, 34, 45-73. [CrossRef]

17. Olivier, D.W.; Heinecken, L. Beyond food security: women's experiences of urban agriculture in Cape Town. Agric. Hum. Values 2017, 34, 743-755. [CrossRef]

18. Tei, F.; Benincasa, P.; Farneselli, M.; Caprai, M. Allotment Gardens for Senior Citizens in Italy: Current status and technical proposals. Acta Hortic. 2010, 881, 91-96. [CrossRef]

19. He, B.J.; Zhu, J. Constructing community gardens? Residents' attitude and behaviour towards edible landscapes in emerging urban communities of China. Urban For. Urban Green. 2018, 34, 156-165. [CrossRef]

20. Fischer, L.K.; Brinkmeyer, D.; Karle, S.J.; Cremer, K.; Huttner, E.; Seebauer, M.; Nowikow, U.; Schütze, B.; Voigt, P. Biodiverse edible schools: Linking healthy food, school gardens and local urban biodiversity. Urban For. Urban Green. 2018, 40, 35-43. [CrossRef]

21. Klepacki, P.; Kujawska, M. Urban Allotment Gardens in Poland: Implications for Botanical and Landscape Diversity. J. Ethnobiol. 2018, 38, 123-137. [CrossRef]

22. Clarke, L.W.; Jenerette, G.D. Biodiversity and direct ecosystem service regulation in the community gardens of Los Angeles, CA. Landsc. Ecol. 2015, 30, 637-653. [CrossRef]

23. Dawson, A.; Richards, R.; Collins, C.; Reeder, A.I.; Gray, A. Edible gardens in early childhood education settings in Aotearoa, New Zealand. Health Promot. J. Aust. 2013, 24, 214-218. [CrossRef] [PubMed]

24. Collins, C.; Richards, R.; Reeder, A.I.; Gray, A.R. Food for thought: Edible gardens in New Zealand primary and secondary schools. Health Promot. J. Aust. 2015, 26, 70-73. [CrossRef] [PubMed]

25. Kosack, L. Die Essbare Stadt Andernach. Urbane Landwirtschaft im öffentlichen Raum. Standort 2016, 40, 138-144. [CrossRef]

26. Kulak, M.; Graves, A.; Chatterton, J. Reducing greenhouse gas emissions with urban agriculture: A Life Cycle Assessment perspective. Landsc. Urban. Plan. 2013, 111, 68-78. [CrossRef]

27. Smith, V.M.; Harrington, J.A. Community Food Production as Food Security: Resource and Economic Valuation in Madison, Wisconsin (USA). J. Agric. Food Syst. Community Dev. 2014, 4, 61-80. [CrossRef]

28. Orsini, F.; Gasperi, D.; Marchetti, L.; Piovene, C.; Draghetti, S.; Ramazzotti, S.; Bazzocchi, G.; Gianquinto, G. Exploring the production capacity of rooftop gardens (RTGs) in urban agriculture: The potential impact on food and nutrition security, biodiversity and other ecosystem services in the city of Bologna. Food Secur. 2014, 6, 781-792. [CrossRef]

29. Crush, J.; Caesar, M. City Without Choice: Urban Food Insecurity in Msunduzi, South Africa. Urban. Forum 2014, 25, 165-175. [CrossRef]

30. Goedele, V.D.B.; Maertens, M. Horticultural exports and food security in developing countries. Glob. Food Secur. 2016, 10, 11-20.

31. Gido, E.O.; Ayuya, O.I.; Owuor, G.; Bokelmann, W. Consumer Acceptance of Leafy African Indigenous Vegetables: Comparison Between Rural and Urban Dwellers. Agric. Food Econ. 2017, 5, 346-361. [CrossRef]

32. Luan, B.; Wang, X.; Huang, S.H.; Shao, W.W.; Chen, J.X. Design exploration of edible landscape in Chinese. Landsc. Archit. 2017, 9, 36-42.

33. Zheng, G.W.; Wen, J.Y. Feasibility analysis of edible landscape in space landscape planning of nursing home. Archit. Cult. 2019, 6, 190-191.

34. Liu, Y.L.; Xu, J.L.; Yin, K.L. Participatory construction of high density urban community public space-taking community garden as an example. Landsc. Archit. 2019, 26, 13-17.

35. Weinberger, K.; Lumpkin, T.A. Diversification into Horticulture and Poverty Reduction: A Research Agenda. World Dev. 2007, 35, 1464-1480. [CrossRef]

36. Zezza, A.; Tasciotti, L. Urban agriculture, poverty, and food security: Empirical evidence from a sample of developing countries. Food Policy 2010, 35, 265-273. [CrossRef]

37. Gregory, M.M.; Leslie, T.W.; Drinkwater, L.E. Agroecological and social characteristics of New York city community gardens: Contributions to urban food security, ecosystem services, and environmental education. Urban. Ecosyst. 2016, 19, 763-794. [CrossRef] 
38. Dietary Guidelines for Chinese Residents. 2016. Available online: http://dg.cnsoc.org/article/2016b.html (accessed on 10 December 2019).

39. McClintock, N.; Cooper, J.; Khandeshi, S. Assessing the potential contribution of vacant land to urban vegetable production and consumption in Oakland, California. Landsc. Urban Plan. 2013, 111, 46-58. [CrossRef]

40. Al-Delaimy, W.K.; Webb, M. Community gardens as environmental health interventions: Benefits versus potential risks. Curr. Env. Health Rep. 2017, 4, 252-265. [CrossRef]

41. Clarke, L.W.; Li, L.; Jenerette, G.D.; Yu, Z. Drivers of plant biodiversity and ecosystem service production in home gardens across the Beijing Municipality of China. Urban Ecosyst. 2014, 17, 741-760. [CrossRef]

42. Teig, E.; Amulya, J.; Bardwell, L.; Buchenau, M.; Marshall, J.A.; Litt, J.S. Collective Efficacy in Denver, Colorado: Strengthening Neighborhoods and Health through Community Gardens. Health Place 2009, 15, 1115-1122. [CrossRef]

43. Guitart, D.; Pickering, C.; Byrne, J. Past results and future directions in urban community gardens research. Urban. Urban. Green. 2012, 11, 364-373. [CrossRef]

44. Leuven, J.R.F.W.; Rutenfrans, A.H.M.; Dolfing, A.G.; Leuven, R.S.E.W. School gardening increases knowledge of primary school children on edible plants and preference for vegetables. Food Sci. Nutr. 2018, 6, 1960-1967. [CrossRef] [PubMed]

45. Kingsley, J.; Townsend, M. 'Dig in' to social capital: Community gardens as mechanisms for growing urban social connectedness. Urban Policy Res. 2006, 24, 525-537. [CrossRef]

46. Millar, J.; Roots, J. Changes in Australian agriculture and land use: Implications for future food security. Int. J. Agric. Sustain. 2012, 10, 25-39. [CrossRef]

47. Kimura, A.H.; Nishiyama, M. The chisan-chisho movement: Japanese local food movement and its challenges. Agric. Hum. Values 2008, 25, 49-64. [CrossRef]

48. Santandreu, A.; Gome, P.A.; Terrile, R.; Ponce, M. Urban agriculture in Montevideo and Rosario: A response to crisis or a stable component of the urban landscape? Urban. Agric. Mag. 2009, 22, 12-13.

49. Clark, K.H.; Nicholas, K.A. Introducing urban food forestry: A multifunctional approach to increase food security and provide ecosystem services. Landsc. Ecol. 2013, 28, 1649-1669. [CrossRef]

50. Castro, J.; Ostoić, S.K.; Cariñanos, P.; Fini, A.; Sitzia, T. “Edible” urban forests as part of inclusive, sustainable cities. Unasylva 2018, 69, 59-65.

51. Hu, T.; Ju, Z.S.; Zhou, W. Regional pattern of grain supply and demand in China. Acta Geogr. Sin. 2016, 71, 1372-1383.

52. He, W.; Li, H. Study on space carrier, design concept and technology of edible landscape in community. Landsc. Arch. 2017, 9, 43-49.

53. Chen, C.R. Edible landscape-A new approach to the construction of beautiful rural landscape. Chin. Hortic. Abstr. 2017, 33, 156-158.

54. Pourias, J.; Aubry, C.; Duchemin, E. Is food a motivation for urban gardeners? Multifunctionality and the relative importance of the food function in urban collective gardens of Paris and Montreal. Agric. Hum. Values 2015, 33, 257-273. [CrossRef]

55. Sunwar, S.; Thornstrom, C.-G.; Subedi, A.; Bystrom, M. Home gardens in western Nepal: Opportunities and challenges for on-farm management of agrobiodiversity. Biodivers. Conserv. 2006, 15, 4211-4238. [CrossRef]

(C) 2019 by the authors. Licensee MDPI, Basel, Switzerland. This article is an open access article distributed under the terms and conditions of the Creative Commons Attribution (CC BY) license (http://creativecommons.org/licenses/by/4.0/). 